\title{
Wellcome shoulders its share of blame for Oxford debacle
}

\section{London}

It has been a difficult year for the Wellcome Trust Centre for the Epidemiology of Infectious Diseases at the University of Oxford. Two inquiries have been picking their way through the centre, and its director - epidemiologist Roy Anderson - was suspended pending these and other investigations.

Last week a series of bombshells hit the centre in the form of a management audit, an interim financial audit, and Anderson's resignation (see Nature 404, 696; 2000). The management audit, in the words of Mike Dexter, director of the Wellcome Trust, "pulls no punches". Its findings include autocratic management and deep divisions both within the centre and in its relations with the university's zoology department, within which the centre is based.

Responsibility is divided between Anderson, the department of zoology, the University of Oxford and the Wellcome Trust. In particular, the trust is blamed for not pursuing management problems, even though they were known about for some time. "There are no excuses," says Dexter, adding that nothing has been hidden in the report.

The financial audit provisionally found that staff broke trust rules by not declaring commercial contracts. "We have conditions and we expect people to abide by them," says Dexter. He emphasizes that he does not want the trust to have to police its researchers, and is wary of introducing any rigidity or bureaucracy. But he is keen to ensure that grant holders, who are often not fully aware of grant conditions, abide by trust rules.

The financial audit found no evidence of financial impropriety at the centre. But it did find that there was no mechanism to record 'cross-subsidy'. What this means is that there was no way of knowing if trust time or equipment was used for contract work. Dexter says the trust has learned from this.

Central to this affair is Anderson, a charismatic and highly regarded researcher who is also widely seen as autocratic. As a director of the centre, it was his responsibility to ensure that staff disclosed these contracts (he is also a governor of the Wellcome Trust). In fact, one of Anderson's own companies hired trust researchers to do consultancy work for a pharmaceutical company.

To make matters worse, Anderson failed to disclose that he held one third of the equity of this company, as well as being a scientific director (trust rules permit only 5 per cent equity to be held). "There has got to be transparency - in particular when one is a director

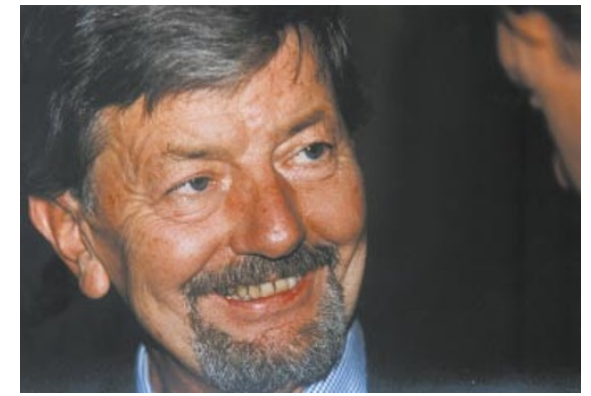

Dexter: stresses the need for 'transparency'

in financial matters at the centre.

and governor," says Dexter. Speculation is mounting that Anderson will have to step down as a governor; Dexter simply says that discussions are under way.

But many staff at the centre are angry that Anderson had to resign. One says that nearly 90 per cent of staff support him and that he provided direction and scientific vision. The report says that Anderson has strong support from his own group, from administrative and support staff, and from junior staff.

Another staff member says Anderson bruised too many egos at Oxford in his desire to change things. "I'm not saying Roy is a saint, but as far as directorship of centre goes, people are very shocked and can't understand why he can't return," says one.

While the trust is being rocked by internal upheavals, it is also facing criticism over its role in the decision to site the new AngloFrench synchrotron Diamond at Rutherford Appleton Laboratories (RAL) in Oxfordshire (see Nature 404, 323; 2000). It has been accused, says Dexter, of "bullying" the government over the site selection.

According to Dexter, the trust initially favoured an open competition, only to be told by government officials that it had to be at RAL. A more senior government minister then said it had to be sited at the rival Daresbury Laboratory in northern England.

After a year of delay, the government settled on RAL only after the decision had been referred to Prime Minister Tony Blair. The decision was contested by those who argue that regional interests should balance what they claim is a marginal scientific case in favour of Rutherford. When the announcement was made, the finger of blame was pointed squarely at the Wellcome Trust.

But Dexter emphasizes that, as a charity, the trust has a responsibility to ensure that its decisions are made on a scientific basis, and are not swayed by other factors. Having chosen RAL, Wellcome was reluctant to change its mind. "We think the case is compelling," says Dexter.

\section{Politicians seek to block human-gene patents in Europe}

Munich

Two European politicians last week launched an initiative, called SOS Human Genome, proposing a moratorium on implementing the European Commission's directive for harmonizing biotechnology patents in the European Union (EU).

The directive is due to be ratified by EU member states by the end of June. But supporters of the moratorium want the "suspension of all patent attributions on the human genome".

The push for a moratorium originated in the Council of Europe. A report arguing that human material — including genes - should not become private property was adopted last week by the science committee of the Council of Europe's parliamentary assembly. It will be debated by the full assembly in June.

The report was prepared by Wolfgang Wodarg, a social-democrat member of the German parliament, and Jean-François Mattei, a conservative member of the French parliament and professor of medical genetics at the children's Hôpital de la Timone in Marseille. If the report is adopted, the Council of Europe's member states would have to "reconsider all biotechnology laws and their consequences".

Wodarg, a physician who is also spokesman for the German government's new 'enquête' committee on bioethics (see Nature 404, 692; 2000), says he hopes that various actions - including a web-based petition against the patenting of human genes - will raise public awareness and encourage parliamentarians to vote down any national attempt to ratify the commission's directive.The European Commission would then have to take the rebel countries to the European Court.

Wodarg also hopes the challenge on the directive will force the European Patent Office (EPO) temporarily to stop issuing patents on genes, plants and animals until the legal position is clear.

An EPO spokeswoman says it is too early to comment on the issue. The EPO has recently amended its own convention in line with the EU directive and is issuing such patents after a four-year moratorium (see Nature 400, 395; 1999).

Volker Mahlbacher, patent manager at the German biotechnology company Qiagen, says that if the German parliament rejects the directive, it could raise the question of whether to stay in Germany.
Alison Abbott \& Ulrike Hellerer 